\title{
Assessing the conservation status of the tiger Panthera tigris at priority sites in Peninsular Malaysia
}

\author{
Antony J. Lynam, Ruth Laidlaw, Wan Shaharuddin Wan Noordin, Sivananthan Elagupillay and \\ Elizabeth L. Bennett
}

\begin{abstract}
Wildlife managers require status and distribution information for informed decisions. Recognizing the tiger's globally threatened status and potential as an umbrella species for protection of forested landscapes, camera trap surveys for tigers and other large mammals have been conducted since 1997 in Peninsular Malaysia with the aim of assessing the population status of tigers in the Peninsula. Results from surveys at nine sites between December 1997 and December 1999 are reported here. Tigers were confirmed from six sites in the Main Range and Greater Taman Negara landscape, with multiple locations inside putative priority tiger areas. Although the data were collected 8 years ago, they are supplemented with more recent information, including tiger-human conflict investigations during 2000-2005 that indicate tiger persistence at these sites.
\end{abstract}

Tiger density estimates were 0.51-1.95 tigers per $100 \mathrm{~km}^{2}$. With results from other surveys, this suggests a national population of up to several hundred tigers. A thorough survey, with sufficient resources, should be carried out in the future to derive a more reliable tiger population estimate for Malaysia. Key threats are habitat loss and fragmentation, hunting of prey, commercial trade in tiger parts, and harassment and displacement. Recommendations for the recovery of tigers in Peninsular Malaysia are provided.

Keywords Conservation status, Panthera tigris, Peninsular Malaysia, surveys, tiger, wildlife management.

This paper contains supplementary material that can be found online at http://journals.cambridge.org

\section{Introduction}

To plan for conservation of tigers, knowledge of their conservation status and the threats to their existence is required. Since 1997 potential tiger habitat across the species' global range has been identified, and remnant vegetation divided into grades of tiger habitat representing high, medium or low probability of tiger population persistence, or so-called Tiger Conservation Units (Dinerstein et al., 1997). Sixteen such Units overlap Peninsular Malaysia, where tigers have been considered threatened with extinction for decades (Blanchard, 1977). However, knowledge of the status of tigers in the wild in these Units is poor (Topani, 1990; Elagupillay \& Wan Shahruddin, 1999). Surveys and tiger-livestock conflicts during the 1980s and 1990s indicated the

Antony J. Lynam (Corresponding author), Ruth Laidlaw and Elizabeth L. Bennett Wildlife Conservation Society, 2300 Southern Boulevard, New York 10460, USA. E-mail tlynam@wcs.org

Wan Shaharuddin Wan Noordin and Sivananthan Elagupillay Department of Wildlife and National Parks, KM 10 Jalan Cheras, 56100 Kuala Lumpur, Malaysia.

Received 2 January 2006. Revision requested 10 July 2006

Accepted 24 October 2006. existence of some tigers (Elagupillay, 1983, 1984; Ratnam et al., 1995) but most information was through unconfirmed reports (Rabinowitz, 1999).

Recognizing the paucity of information on tigers, and wanting to mitigate effects on tiger survival of future intrusions into these habitats, the Malaysian Department of Wildlife and National Parks (DWNP) embarked on a programme to: (1) determine distribution and status of tigers in Peninsular Malaysia and calibrate the model of putative priority areas (Dinerstein et al., 1997); (2) collect information on tiger numbers, movements, behaviour, home range size and habitat use in a key tiger site identified from the survey programme; and (3) train Malaysian wildlife biologists in surveying and studying tigers to facilitate the future management and conservation of tiger populations in the region.

This study, conducted by DWNP and the Wildlife Conservation Society (WCS), addressed goals (1) and (3). Specifically, several types of information on tigers are important for their effective management in Malaysia: (a) distribution across potential habitats, (b) comparative abundance within and between habitats, and (c) threats specific to tigers and their prey, especially poaching. This study addressed (a) by determining patterns of detection or non-detection of tigers using camera traps, 
(b) by sampling tiger abundance using camera traps, and (c) by records of human intrusion from camera traps, field observations, and general appraisals of habitat condition and human disturbance from other studies (Laidlaw, 2000). A study by DWNP and the University of Florida at Gainesville to address goal (2) is reported elsewhere (Kawanishi \& Sunquist, 2004).

\section{Study sites}

Tiger surveys at nine forest sites spanned the states of Perak, Terengannu, Kelantan and Pahang (Fig. 1). The sites (1) have the potential to support tiger populations in the long-term (Dinerstein et al., 1997); (2) represent varying forest types and management histories (logged and unlogged forest, protected forest and forest reserves, forest fragments and continuous forest, edge and core forest, tiger conflict and non-conflict zones; Table 1); (3) have information available suggesting tiger presence (DWNP, unpubl. data). Four sites are inside the high priority Tiger Conservation Unit \#129, one in the medium-priority Unit \#130, one adjacent to the low priority Unit \#134, and one inside Taman Negara National Park. Two other sites are in forest reserves legally protected from clearance but where selective timber extraction may be licensed. Full descriptions of the sites are in DWNP/WCS (2004).

\section{Methods}

Camera traps (CamTrak South Inc., Georgia, USA) consisting of a weatherproof Infinity Mini DLX Olympus camera with a $35 \mathrm{~mm}$ lens and flash, and a passive infrared sensor, housed in a waterproof casing, were triggered and a photograph taken when the sensor detected a difference in heat and motion across a beam in front of the device. Cameras were programmed to record the date and time on 400 ISO film, with a 3-minute time delay to forestall lingering animals from rapidly filling the film. Camera traps were mounted $40 \mathrm{~cm}$ above the ground, 3-5 $\mathrm{m}$ (the focal length of the camera) from the middle of a trail, and usually left for 4-6 weeks, set for continuous operation day and night (one trap-night $=$ one $24 \mathrm{~h}$ period). Information on camera trap set-up and retrieval allowed determination of the number of trap nights over which a camera trap was functional. Surveys were conducted between December 1997 and December 1999 inclusive (Table 2).

Camera traps were placed to maximize tiger detection probability ( $p$; Karanth \& Nichols, 1998, 2002): trail junctions, ridgeline trails, water crossings, passes, and where tracks of tigers and/or tiger prey species were detected during reconnaissance. At each study site camera traps were established on a $10 * 4 \mathrm{~km}$ grid. Single camera traps were placed at optimal locations inside $15-20 * 1 \mathrm{~km}^{2}$ cells so that no holes in the web of trap locations exceeded a tiger's home range in size (Karanth \& Nichols, 2002). At $\leq 5$ additional locations, usually where tiger signs were detected, paired traps were positioned on opposite sides of the trail/road to allow simultaneous photography of both sides of a tiger, thereby permitting identification of individual animals from stripe patterns. Such paired camera traps were dispersed for maximum spatial coverage. On average $19 \pm 1$ camera trap set-ups (range: $13-27$; Table 2) were used at each site. For additional details of methods see Laidlaw (1999).

Independent events (detections) comprised (1) consecutive photographs of different individual conspecifics or (2) consecutive photographs of conspecifics more than 10 minutes apart. Photographs without inscribed times (reflecting flash overexposure or errors in setting the camera trap) were not included in analyses. Location-specific relative abundance indices (RAI) were calculated for tigers following O'Brien et al. (2003) as the number of detections divided by the number of functional trap nights. This index, which was scaled to detections per 100 trap-nights, should increase with population density.

Time constraints and access difficulties rendered markrecapture methods (as recommended for estimating tiger abundance; Karanth \& Nichols, 2002) impractical, and these results cannot be compared with abundance estimates from mark-recapture studies. However, to compare abundance within this study, naïve density of tigers, $\hat{D}$, was calculated using the number of tiger individuals captured in camera traps, $\hat{N}$, and by assuming a sampling effective area, $\hat{A}$, at each site. This abundance estimate was translated into density by:

$$
\hat{D}^{\prime}=\frac{\hat{N}^{\prime}}{\hat{A}(W)}
$$

where $\hat{A}(W)$ is the sampling area with buffer width $W$. $\hat{A}(W)$ was calculated by linking the outermost locations of camera traps and adding a buffer with radius $W$ equivalent to half the absolute maximum distance moved (AMDM) between recaptures of individual tigers. AMDM is superior to mean maximum distance moved (MMDM) when sample sizes are small because MMDM tends to underestimate $W$ (Kawanishi, 2002) thus inflating estimated densities (Soisalo \& Cavalcanti, 2006).

Spatial extent of human use at each site, and hence potential threats to tigers, was measured as the proportion of sampling locations where camera traps photographed people. 


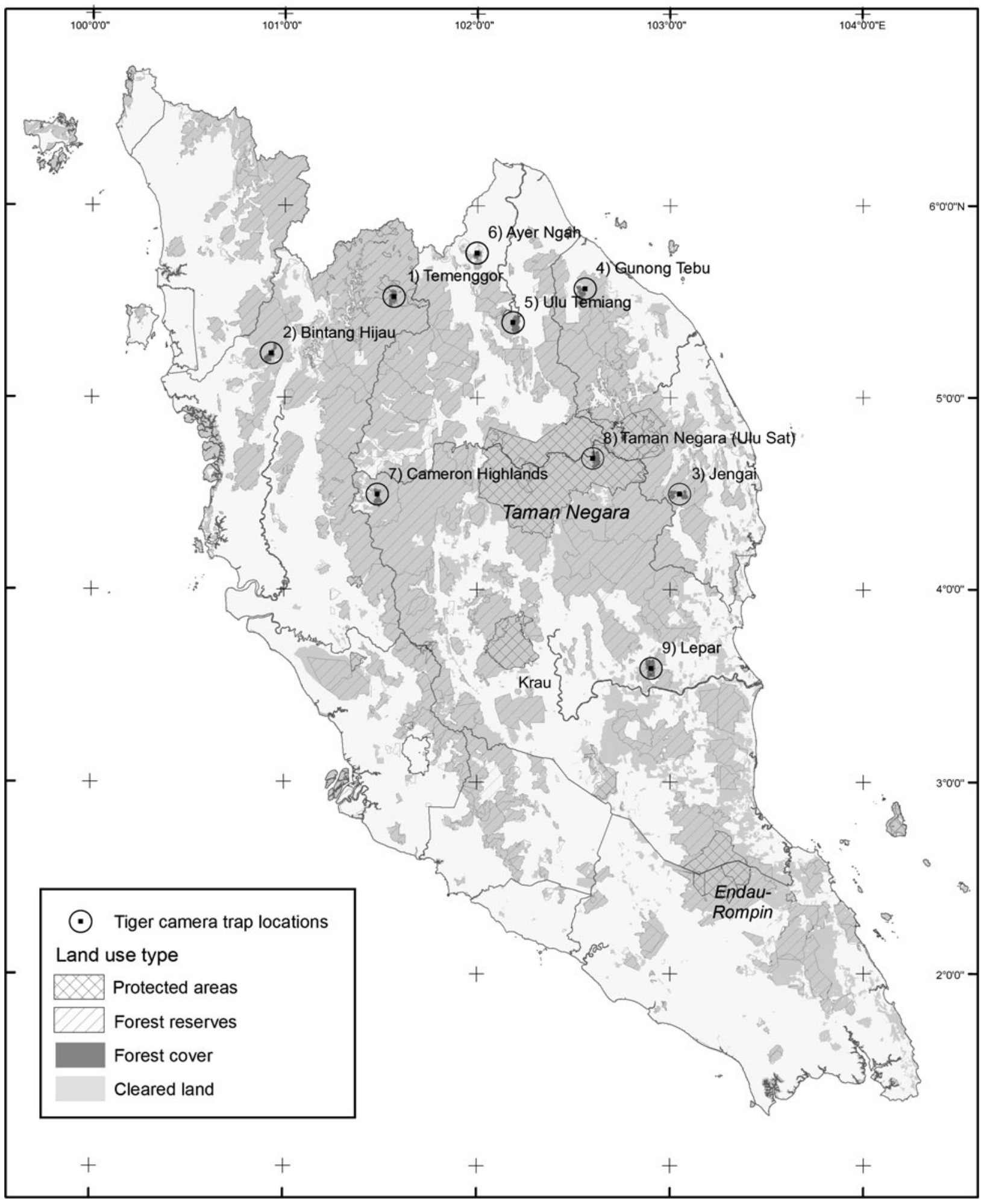

Fig. 1 Location of nine sites surveyed for tigers (Table 1) in Peninsular Malaysia during December 1997-December 1999. The numbered locations give the approximate position of each study site; locations of individual camera traps are not shown. A tenth site also shown here, Krau Wildlife Reserve, was surveyed subsequently during 2000 (Laidlaw, 2002). 
Table 1 The location, area and logging history of the nine sites surveyed for tiger in Peninsular Malaysia (Fig. 1).

\begin{tabular}{|c|c|c|c|}
\hline Site & Location $^{1}$ & Area $^{2}$ & Logging history \\
\hline 1. Temenggor & Core & Continuous & Unlogged \\
\hline 2. Bintang Hijau & Core & $>1,400 \mathrm{~km}^{2}$ & Unlogged/logged ${ }^{3}$ \\
\hline 3. Jengai & Core & Continuous & Unlogged $/ \operatorname{logged}^{3}$ \\
\hline 4. Gunong Tebu & Edge & Continuous & Unlogged/logged ${ }^{3}$ \\
\hline 5. Ulu Temiang & Edge & $<160 \mathrm{~km}^{2}$ & Logged \\
\hline 6. Ayer Ngah & Edge/converted & $<40 \mathrm{~km}^{2} /$ converted & Logged/scrub \\
\hline 7. Cameron Highlands & Edge & Continuous & Logged \\
\hline 8. Taman Negara (Ulu Sat) & Core & Continuous & Unlogged \\
\hline 9. Lepar & Edge & Continuous & Logged \\
\hline
\end{tabular}

${ }^{1}$ Core, plot was located centrally within a Forest Reserve and was totally surrounded by natural forest; Edge, plot was located on the edge of a Forest Reserve

${ }^{2}$ Continuous, area of forest that is part of the large block of forest covering the Main Range of mountains and Taman Negara

${ }^{3}$ Unlogged/logged, study site was a mosaic of unlogged and logged forest

\section{Results}

A total of 174 camera traps deployed across 151 sampling locations at the nine study sites recorded 2,371 photographs from 6,259 trap-nights (Table 2). Apart from tigers, 34 other species of native mammal were positively identified from photographs (Appendix), nearly a third (11 species) of which are threatened or Data Deficient (IUCN, 2007). Mammal species richness cannot be compared between sites because sampling efforts varied and species totals did not reach an asymptote at any of the sites. However, species accumulation rates were relatively high at Ulu Temiang, Gunong Tebu and Lepar, medium at Ayer Ngah, Temenggor and Taman Negara, and low at Bintang Hijau, Jengai and Cameron Highlands. Camera traps recorded at least 11 species of reptiles and birds. Three birds are threatened and three Near Threatened (IUCN, 2007).

Ten individual tigers could be identified from 35 of 51 tiger photographs from 36 sampling locations across the nine sites. Within tiger-occupied sites, tigers were recorded at a mean of $18 \pm \mathrm{SE} 6 \%$ of sampling locations per site. Overall, one tiger was photographed every 122 trap nights. Tigers were not recorded at Taman Negara, Cameron Highlands and Jengai but were detected at almost half the locations at Ulu Temiang. Average tiger detection rate was highest at Ulu Temiang and lowest at Ayer Ngah (Table 3). Between 1 and 3 individual tigers were detected at six sites. Naïve density estimates ranged from $0.51-0.53$ tigers per $100 \mathrm{~km}^{2}$ at Lepar, Gunong Tebu and Ayer Ngah to 1.95 tigers per $100 \mathrm{~km}^{2}$ at Temenggor (Table 3).

Camera traps recorded people at a mean $18 \pm$ SE $4 \%$ (range $0-33 \%$ ) of sampling locations across the nine sites. No people were recorded at Bintang Hijau whereas a third of traps photographed people at Ulu Temiang and Ayer Ngah. Human traffic represented a mean $4 \pm$ SE $1 \%$ of all traffic (range $0-8 \%$ ), and appeared highly localized, especially at Ayer Ngah, Cameron Highlands and Jengai, with a few sampling locations detecting heavy traffic but most not detecting any.

\section{Discussion}

The data presented here were collected 8 years ago (1997-1999), a short period in ecological terms and equivalent to $c .2$ tiger generations (Smith \& McDougal, 1991).

Table 2 Dates, sampling effort and camera trapping results for tiger surveys at nine sites (Table 1, Fig. 1) in Peninsular Malaysia.

\begin{tabular}{|c|c|c|c|c|}
\hline Site & Date & $\begin{array}{l}\text { No. of tigers captured } \\
\text { (recaptured) }\end{array}$ & $\begin{array}{l}\text { No. of camera } \\
\text { traps deployed }\end{array}$ & $\begin{array}{l}\text { No. of } \\
\text { trap nights }\end{array}$ \\
\hline 1. Temenggor & $10 / 12 / 1997-2 / 3 / 1998$ & $2(4)$ & 22 & 785 \\
\hline 2. Bintang Hijau & $12 / 2 / 1998-26 / 3 / 1998$ & $2(4)$ & 19 & 646 \\
\hline 3. Jengai & 28/4/1998 - 4/6/1998 & 0 & 15 & 467 \\
\hline 4. Gunong Tebu & 26/6/1998 - 27/8/1998 & $1(11)$ & 27 & 807 \\
\hline 5. Ulu Temiang & $30 / 8 / 1998-30 / 9 / 1998$ & $3(11)$ & 21 & 557 \\
\hline 6. Ayer Ngah & 9/10/1998 - 13/11/1998 & 1 & 18 & 562 \\
\hline 7. Cameron Highlands & $7 / 2 / 1999-22 / 3 / 1999$ & 0 & 13 & 495 \\
\hline 8. Taman Negara (Ulu Sat) & 26/5/1999 - 14/8/1999 & 0 & 16 & 768 \\
\hline 9. Lepar & 28/9/1999 - 23/12/1999 & $1(5)$ & 23 & 1,172 \\
\hline Total & & $10(35)$ & 174 & 6,259 \\
\hline
\end{tabular}


Table 3 Maximum distances moved and naïve density estimates for tigers at six sites (Table 1, Fig. 1) in Peninsular Malaysia.

\begin{tabular}{|c|c|c|c|c|c|c|}
\hline Site & $\begin{array}{l}\text { Plot size } \\
\left(\mathrm{km}^{2}\right)\end{array}$ & $\begin{array}{l}\mathrm{AMDM}^{1} \\
(\mathrm{~km})\end{array}$ & $\hat{A}(W)^{2}$ & $\begin{array}{l}\text { No. individual } \\
\text { tigers captured }\end{array}$ & $\begin{array}{l}\text { RAI } \\
(\text { mean } \pm S E)\end{array}$ & $\hat{D}^{3}$ \\
\hline 1. Temenggor & 40 & 4.0 & 112 & 2 & $0.97 \pm 0.42$ & 1.79 \\
\hline 2. Bintang Hijau & 40 & 9.8 & 272 & 2 & $1.66 \pm 0.82$ & 0.74 \\
\hline 4. Gunong Tebu & 40 & 7.0 & 188 & 1 & $1.54 \pm 0.54$ & $0.53^{5}$ \\
\hline 5. Ulu Temiang & 40 & 8.2 & $154^{4}$ & 3 & $2.72 \pm 0.73$ & 1.95 \\
\hline 6. Ayer Ngah & 40 & $7.0^{6}$ & 188 & 1 & $0.17 \pm 0.18$ & $0.53^{5}$ \\
\hline 9. Lepar & 40 & 7.3 & 195 & 1 & $0.61 \pm 0.24$ & $0.51^{5}$ \\
\hline
\end{tabular}

${ }^{1} \mathrm{AMDM}$, absolute maximum distance moved

${ }^{2}$ Boundary width $W=$ AMDM $/ 2$;

${ }^{3}$ Naïve estimate of tiger density (no. per $100 \mathrm{~km}^{2}$ )

${ }^{4}$ Calculated sampling area was larger than size of the reserve so the latter was used to estimate density

${ }^{5}$ No recaptures or single individuals

${ }^{6}$ No recaptures at this site, assumed same AMDM as Gunong Tebu (nearest site)

However, because of the rapid rate at which tropical forests in Asia are changing relative to other continents (Sodhi et al., 2004) and the speed with which tigers can be poached, we invoke findings from related studies and more recent data in drawing conclusions about the conservation status of tigers in Peninsular Malaysia.

In nine sampled forest areas tigers were found in multiple parts of a Level I Tiger Conservation Unit (\#129: Temenggor, Ayer Ngah, Gunong Tebu, Ulu Temiang), in a Level II Unit (\#130: Bintang Hijau) and adjacent to one Level III Unit (\#134: Lepar; Dinerstein et al., 1997). A separate survey of a $450 \mathrm{~km}^{2}$ plot inside Krau Wildlife Reserve (Fig. 1), also part of Unit \#129, found at least two adult tigers (Laidlaw, 2002). Tigers were not detected at three sites: a site in the Cameron Highlands, Ulu Sat in eastern Taman Negara, and Jengai, which lies south-east of Taman Negara. Tigers do inhabit central and western Taman Negara, at Merapoh, Kuala Terengan and Kuala Koh (Kawanishi \& Sunquist, 2004), implying that tiger distribution even within a single contiguous tract of protected primary forest is patchy, and not readily predictable from habitat.

Tiger-human conflict investigations during 2001-2005 confirmed persistence at each site where tigers were recorded in this study (DWNP, unpubl. data; S. Elagupillay, pers. obs.), suggesting potentially stable tiger occurrence at these sites. All except one exceeds $100 \mathrm{~km}^{2}$ (Table 1), a threshold below which tigers, and some other large mammals, may rapidly go extinct (Woodroffe \& Ginsberg, 1998; Laidlaw, 2000). Although tigers currently inhabit Ulu Temiang and Ayer Ngah these small areas have tenuous connections with larger habitat blocks and may not therefore support tigers in the long-term.

Tiger relative abundance varied 10 -fold and the number of individual tigers detected varied three-fold. The naïve estimates of density here (0.51-1.95 tigers per $\left.100 \mathrm{~km}^{2}\right)$ are of the same order as those from capture-recapture studies in Malaysia (1.45-1.87; Kawanishi \& Sunquist, 2004) and elsewhere in South-east Asia (O'Brien et al., 2003; Johnson et al., 2006). Tigers no doubt occur outside the nine sites studied and in other states that we were unable to cover. If the observed naïve densities $\left(0.67 \pm 0.25\right.$ tigers per $\left.100 \mathrm{~km}^{2}\right)$ typify true density across Malaysian tiger priority areas $\left(29,159 \mathrm{~km}^{2}\right.$; Dinerstein et al., 1997) this would suggest several hundred tigers. However, mark-recapture studies using camera traps from other parts of the country are needed to estimate the population reliably. The present tiger population in Malaysia could be conserved by protecting the available habitat and non-depleted prey populations (Kawanishi et al., 2003) and through appropriate management practices inside and outside protected areas. The recent adoption of the National Physical Plan by the Malaysian Government as the spatial planning tool that proposes to establish a central forest spine to protect environmentally sensitive habitats (FDTCP, 2005), if successfully implemented, augers well for the long-term conservation of tiger populations and their habitats in Malaysia.

Tigers need large $\left(>3,000 \mathrm{~km}^{2}\right)$ contiguous areas for long-term viability (Karanth \& Nichols, 2002). In Peninsular Malaysia tiger habitat is fragmented and lost through road and power networks, plantations, urban expansion, dams, irrigation, and other developments. Although two-thirds of hill and montane forests remain, $80 \%$ of lowland forests have been lost and/or fragmented (Wikramanayake et al., 2002). Most small (<100 $\mathrm{km}^{2}$ ) fragments now lack tigers and other predators (Laidlaw, 2000), in turn affecting ungulate prey densities (Ickes, 2001). Tigers require access to rivers, so disturbance of or along rivers (e.g. by roads, dams or housing) can extirpate them from otherwise suitable areas. Habitat fragmentation increases the accessibility of remaining forest, in turn stimulating further degradation 
through various activities, notably hunting (Robinson et al., 1999) both of tigers and their ungulate prey, thereby driving declines in tiger populations (Ramakrishnan et al., 1999; Madhusudan \& Karanth, 2002). Non-vehicular paths, e.g. those of aloewood (Aquilaria spp.) collectors, also facilitate hunting (Abdul Kadir, 1998; Wan Shahruddin, 1998). Aloewood collectors include some Thai and Lao nationals (A.J. Lynam \& R.K. Laidlaw, pers. obs.), and they often leave few signs, which may suggest that their impacts are low (Kawanishi \& Sunquist, 2004). Evidence of hunting by these forest users has been found at several of the sites of this study (Wan Shahruddin, 1998).

In general, tropical forest productivity for large mammals is low, and hence hunting levels must be extremely low to be sustainable (Robinson \& Bennett, 2000); in closed forests, sustainable off-take levels are especially low (Robinson, 2000). Examples of sustainable hunting in such forests are rare, even for more rapidly breeding prey such as ungulates and rodents (Robinson \& Bennett, 2000), let alone for the scarcer carnivores. Sustainability of hunting has not been studied in Peninsular Malaysia but unsustainable hunting is rapidly depleting wildlife populations across parts of tropical Asia (Bennett \& Robinson, 2000; WCS \& TRAFFIC, 2004).

Besides hunting of their prey, tigers themselves are hunted. Commercial trade in wild tigers and tiger parts has occurred in Asia and across the world for centuries (Nowell, 2000) and occurs today in Malaysia (Elagupillay et al., 2001), as in other Asian countries (Shepherd \& Magnus, 2004; Davies, 2005). Rates of the loss of tigers to commercial hunting in Malaysia have never been quantified. Tigers are also killed in retribution for livestock depredation and human injury and both are increasing in frequency in Peninsular Malaysia: between 1988 and 1997, 108 tiger-human incidents and 503 tigerlivestock incidents were reported in four and six states respectively (Elagupillay et al., 2001). The increase in conflicts presumably reflects tigers coming into contact with people as habitats are encroached and their prey base depleted (Woodroffe \& Ginsberg, 1998; Nyhus \& Tilson, 2004). In Malaysia several problem tigers have been taken into captivity, thus depleting the wild population. Tigers are occasionally killed by farmers or when they cannot otherwise be moved but such cases are reported inconsistently.

Harassment from humans may disrupt tiger behaviour and prey populations (Griffiths \& van Schaik, 1993). Human intrusions were evident at eight of our nine survey areas, across up to a third of sampling locations. Tiger activity may be disrupted by human traffic, especially in high human-use areas (Laidlaw \& Shaharuddin, 1998), and this may underlie their low density or absence where human traffic was most intense (Ayer Ngah, Cameron Highlands and Jengai).

In Malaysia few tigers remain, areas of sufficient size to support tigers are limited, and threats are diverse but as yet unquantified. Management efforts should thus focus on protecting and restoring tiger populations in a few priority landscapes. The Main Range (Fig. 1) is the first priority landscape given its large size (c. 20,000 $\mathrm{km}^{2}$ ) and connectivity with important tiger habitats in southern Thailand (Dinerstein et al., 1997). The next priority, the Greater Taman Negara Landscape (c. 15,000 km²), has an existing level of protection because of the presence of rangers in Taman Negara. Both landscapes contain multiple sites with tigers and their prey species (Appendix; Laidlaw, 2002; Kawanishi \& Sunquist, 2004). Sites that contain at least several individuals, especially breeding females, should be targeted. Priority sites include Royal Belum State Park $\left(1,175 \mathrm{~km}^{2}\right)$ and Taman Negara $\left(4,343 \mathrm{~km}^{2}\right)$, with secondary priority sites being Bintang Hijau, identified in this study, and Krau Wildlife Reserve, where tigers persist in small numbers (Laidlaw, 2002). A few tigers may persist in Endau-Rompin (DWNP, unpubl. data) but the site is of low priority because it is small $\left(891 \mathrm{~km}^{2}\right)$ and embedded in a heavily fragmented landscape with only tenuous connections to the Greater Taman Negara Landscape. Measures that need to be taken to restore tiger numbers to their full potential in these landscapes (Kawanishi et al., 2003) include:

Short-term actions (1) Mark-recapture studies using camera traps to obtain statistically defensible tiger density estimates at key sites. (2) Enforcement training for park rangers and staff who work outside protected areas, and implementation of anti-poaching strategies. Basic training for Taman Negara staff has been provided through the CITES Monitoring of the Illegal Killing of Elephants (MIKE) programme. People in local communities could be recruited to provide information about poaching, supplementing enforcement staff efforts. Wildlife protection strategies implemented for tiger areas elsewhere (Lynam \& Soriyun, 2004; Lynam et al., 2006b) could serve as models for Malaysian sites. (3) Increased communication and collaboration between Malaysian police, customs and wildlife departments, and their counterparts in neighbouring countries would reduce trafficking of tiger products. This is central to the goals of the new ASEAN Wildlife Enforcement Network (Bazilchuk, 2006). (4) Information should be assembled to quantify the rate at which, and reasons why, tigers are killed in Peninsular Malaysia; such information would garner public support for conservation and help mitigate future tiger-human conflicts. Alternatives to killing or removing problem tigers into captivity, such as translocating animals to other wild populations (Goodrich \& Miquelle, 2005) should be explored. 
Long-term actions (1) Many protected areas are $<500 \mathrm{~km}^{2}$ and will not support viable tiger populations. New protected areas should be established in key tiger areas, and existing areas expanded. Many of the 32 protected areas proposed by the federal government between 1976-1998, if designated, could meet the requirements for tiger conservation. (2) For tigers to persist in human-dominated landscapes, areas that support breeding populations and the habitat corridors that link them must be retained (Wikramanayake et al., 2004; Linkie et al., 2006). Geographic information systems and remote sensing tools can estimate rates of habitat loss, project future loss and predict creation of forest edges (Kinnaird et al., 2002). The loss of certain areas, such as corridors between Taman Negara and Krau Wildlife Reserve, and between Taman Negara and the Main Range (Fig. 1), may hinder tiger dispersal. The new Selangor Heritage Park $\left(1,070 \mathrm{~km}^{2}\right)$ linking all catchment areas of Selangor State to the Main Range, will help to maintain habitat linkages (Economic Planning Unit, 2006). (3) Camera-trap photographs could be used creatively to increase public awareness and motivate field staff. A tiger education programme for park rangers was introduced in 2004 using camera-trap photographs and a standard teaching curriculum (Naiman, 2002). (4) Management Plans such as that developed for Krau Wildlife Reserve (DWNP/DANCED, 2002) should be developed and implemented for other key tiger sites.

Results of field surveys, coupled with information on specific threats in tiger areas, provide the basis for conservation planning for tigers (Lynam et al., 2006a). Information derived from this study, with the results of separate studies of tiger ecology and distribution (DWNP/DANCED, 2002; Kawanishi \& Sunquist, 2004), collectively provide the foundation for the ongoing revision of Malaysia's National Tiger Action Plan. Information from this report has already been used to update a region-wide tiger conservation planning analysis (Sanderson et al., 2006).

\section{Acknowledgements}

This project was possible through interest and assistance of DWNP staff Musa Nordin, Director-General, Sahir Othman, Director of Protected Areas Division and former Director of Research and Wildlife Conservation, Jasmi Abdul, Deputy Director-General (Operations) and former Director of Perak, Mohd. Shamsuddin Shaari, Ecotourism Division and former Director of Terengganu, and Rahim Ahmad, Director of Kedah and former Director of Kelantan. Permissions to conduct research in Peninsular Malaysia were provided by the Economic Planning Unit, Prime Minister's Department. William Duckworth, Tim O'Brien and Joshua Ginsberg provided comments that improved the manuscript. Tunku Nazim kindly provided maps and figures.

\section{References}

Abdul Kadir, A.H. (1998) Potential threats to Sumatran rhinoceros population in Belum Valley. Journal of Wildlife Parks (Malaysia), 16, 156-7.

Bazilchuk, N. (2006) Wildlife interpol cracks down on organized crime. Conservation in Practice, $7,38$.

Bennett, E.L. \& Robinson, J.G. (2000) Hunting of Wildlife in Tropical Forests. Implications for Biodiversity and Forest Peoples. The World Bank, Washington, DC, USA.

Blanchard, R.F. (1977) Tigers in Malaysia: Battered, Beaten and on the Verge of Extinction. Unpublished Report. Department of Wildlife and National Parks, Kuala Lumpur, Malaysia.

Davies, B. (2005) Black Market: Inside the Endangered Species Trade in Asia. Earth Aware Editions, San Rafael, USA.

Dinerstein, E., Wikramanayake, E., Robinson, J., Karanth, U., Rabinowitz, A., Olson, D., Mathew, T., Hedao, P., Connor, M., Hemley, G. \& Bolze, D. (1997) A Framework for Identifying High Priority Areas and Actions for the Conservation of Tigers in the Wild. WWF-US and Wildlife Conservation Society, Washington, DC, USA.

DWNP/DANCED (Department of Wildlife and National Parks/Danish Cooperation for Environment and Development) (2002) Krau Wildlife Reserve Management Plan. DWNP, Kuala Lumpur, Malaysia.

DWNP/WCS (2004) Status, Ecology and Conservation of Tigers in Peninsular Malaysia. Final Report. DWNP/WCS, Kuala Lumpur, Malaysia.

Economic Planning Unit (2006) Ninth Malaysia Plan, 2006-2010. Percetakan Nasional Malaysia Berhad, Kuala Lumpur, Malaysia.

Elagupillay, S.T. (1983) Livestock depredation problem by tiger in cattle farms. Journal of Wildlife and Parks (Malaysia), 2, 144-150.

Elagupillay, S.T. (1984) Territorial range of an adult tigress at Behrang Ulu Cattle Farm. Journal of Wildlife and Parks (Malaysia), 3, 63-67.

Elagupillay, S.T., Laidlaw, R. \& Wan Shahruddin, W.N. (2001) Tiger conservation and the Department of Wildlife and National Parks (DWNP) Peninsular Malaysia. Journal of Wildlife and Parks (Malaysia), 19, 89-97.

Elagupillay, S.T. \& Wan Shahruddin, W.N. (1999) Conservation of Tigers in Peninsular Malaysia and Related Issues. Paper presented at the Millennium Tiger Conference, New Delhi, India.

FDTCP (2005) National Physical Plan. Federal Department of Town and Country Planning, Kuala Lumpur, Malaysia.

Goodrich, J.M. \& Miquelle, D.G. (2005) Translocation of problem Amur tigers Panthera tigris altaica to alleviate tiger-human conflicts. Oryx, 39, 454-457.

Griffiths, M. \& van Schaik, C.P. (1993) The impact of human traffic on the abundance and activity periods of Sumatran rainforest wildlife. Conservation Biology, 7, 623-626.

Ickes, K. (2001) Hyper-abundance of native wild pigs (Sus scrofa) in a lowland dipterocarp rainforest of Peninsular Malaysia. Biotropica, 33, 682-690.

IUCN (2007) 2007 IUCN Red List of Threatened Species. IUCN, Gland, Switzerland [http://www.iucnredlist.org, accessed 25 September 2007]. 
Johnson, A., Vongkhamheng, C., Hedemark, M. \& Saithongdam, T. (2006) Effects of human-carnivore conflict on tiger (Panthera tigris) and prey populations in Lao PDR. Animal Conservation, 4, 421-430.

Karanth, K.U. \& Nichols, J.D. (1998) Estimation of tiger densities in India using photographic captures and recaptures. Ecology, 79, 2852-2862.

Karanth, K.U. \& Nichols, J.D. (2002) Monitoring Tigers and Their Prey. Centre for Wildlife Studies, Bangalore, India.

Kawanishi, K. (2002) Population status of tigers (Panthera tigris) in a primary rainforest of Peninsular Malaysia. $\mathrm{PhD}$ thesis, University of Florida, Gainesville, USA.

Kawanishi, K. \& Sunquist, M.E. (2004) Conservation status of tigers in a primary rainforest of Peninsular Malaysia. Biological Conservation, 120, 333-348.

Kawanishi, K., Yatim, S.H., Hashim, A.K.A. \& Topani, R. (2003) Distribution and potential population size of the tiger in Peninsular Malaysia. Journal of Wildlife and Parks (Malaysia), 21, 29-50.

Kinnaird, M.F., Sanderson, E.W., O'Brien, T.G., Wibisono, H.T. \& Woolmer, G. (2002) Deforestation trends in a tropical landscape and implications for endangered large mammals. Conservation Biology, 17, 245-257.

Laidlaw, R. (1999) Tiger camera-trapping methods. Journal of Wildlife and Parks (Malaysia), 16, 127-134.

Laidlaw, R. (2000) Effects of habitat disturbance and protected areas on mammals of Peninsular Malaysia. Conservation Biology, 14, 1639-1648.

Laidlaw, R.K. (2002) A Large Mammal Survey in Krau Wildlife Reserve, 19 August 2000-1 August 2001. DWNP/DANCED, Kuala Lumpur, Malaysia.

Laidlaw, R. \& Shaharuddin, W.N.W. (1998) Activity patterns of the Indochinese tiger (Panthera tigris corbetti) and prey species in Peninsular Malaysia. Journal of Wildlife and Parks (Malaysia), 16, 85-96.

Linkie, M., Chapron, G., Martyr, D.J., Holden, J. \& LeaderWilliams, N. (2006) Assessing the viability of tiger subpopulations in a fragmented landscape. Journal of Applied Ecology, 43, 576-586.

Lynam, A.J., Khaing, S.T. \& Zaw, K.M. (2006a) Developing a national tiger action plan for the Union of Myanmar. Environmental Management, 37, 30-39.

Lynam, A.J. \& Soriyun, M. (2004) A Conservation Management Strategy for the Seima Biodiversity Conservation Area, Southern Mondulkiri: Guidelines for Law Enforcement and Administrative Structure. Wildlife Conservation Society, Phnom Penh, Cambodia.

Lynam, A.J., Venevongphet \& Saypanya, S. (2006b) Towards a Wildlife Protection Strategy for the Nam Et Phou Louey NPA. Wildlife Conservation Society, Vientiene, Lao PDR.

Madhusudan, M.D. \& Karanth, K.U. (2002) Local hunting and the conservation of large mammals in India. Ambio, 31, 49-54.

Naiman, T. (2002) Teachers for Tigers. An Educators Tool Kit for Saving the World's Greatest Cat. Wildlife Conservation Society, New York, USA.

Nowell, K. (2000) Far From A Cure: The Tiger Trade Revisited. TRAFFIC, Cambridge, UK.

Nyhus, P.J. \& Tilson, R. (2004) Characterizing human-tiger conflict in Sumatra, Indonesia: implications for conservation. Oryx, 38, 68-74.

O'Brien, T.G., Kinnaird, M.F. \& Wibisono, H.T. (2003) Crouching tigers, hidden prey: Sumatran tiger and prey populations in a tropical forest landscape. Animal Conservation, 6, 131-139.

Rabinowitz, A. (1999) The status of the Indochinese tiger: separating fact from fiction. In Riding the Tiger: Tiger Conservation in Human Dominated Landscapes (eds J. Seidensticker, S. Christie \& P. Jackson), pp. 148-163. Cambridge University Press, Cambridge, UK.

Ramakrishnan, U., Coss, R.G. \& Pelkey, N.W. (1999) Tiger decline caused by the reduction of large ungulate prey: evidence from a study of leopard diets in southern India Biological Conservation, 89, 113-120.

Ratnam, L., Lim, B.L. \& Nor, A.H. (1995) Mammals of the Sungai Singgor Area in Temengor Forest Reserve, Hulu Perak, Malaysia. Malayan Nature Journal, 48, 409-423.

Robinson, J.G. (2000) Calculating maximum sustainable harvests and percentage offtakes. In Hunting for Sustainability in Tropical Forests (eds J.G. Robinson \& E.L. Bennett), pp. 521-524. Columbia University Press, New York, USA.

Robinson, J.G. \& Bennett, E.L. (eds) (2000) Hunting for Sustainability in Tropical Forests. Columbia University Press, New York, USA.

Robinson, J.G., Redford, K.H. \& Bennett, E.L. (1999) Wildlife harvest in logged tropical forests. Science, 284, 595-596.

Sanderson, E., Forrest, J., Loucks, C., Ginsberg, J., Dinerstein, E., Seidensticker, J., Leimgruber, P., Songer, M., Heydlauff, A., O’Brien, T., Bryja, G., Klenzendorf, S. \& Wikramanayake, E. (2006) Setting Priorities for the Conservation and Recovery of Wild Tigers: 2005-2015. WCS, WWF, Smithsonian and NFWF-STF, New York \& Washington, DC, USA.

Shepherd, C.R. \& Magnus, N. (2004) Nowhere to Hide: The Trade in Sumatran Tiger. TRAFFIC South-east Asia, Selangor, Malaysia.

Smith, J.D. \& McDougal, C. (1991) The contribution of variance in lifetime reproduction to effective population size in tigers. Conservation Biology, 5, 484-490.

Sodhi, N.S., Koh, L.P., Brook, B.W. \& Ng, P.K.L. (2004) Southeast Asian biodiversity: an impending disaster. Trends in Ecology and Evolution, 19, 654-660.

Soisalo, M.K. \& Cavalcanti, S.M.C. (2006) Estimating the density of a jaguar population in the Brazilian Pantanal using camera-traps and capture-recapture sampling in combination with GPS radio-telemetry. Biological Conservation, 129, 487-496.

Topani, R. (1990) Status and distribution of tiger in Peninsular Malaysia. Journal of Wildife and Parks (Malaysia), 9, 71-102.

Wan Shahruddin, W.N. (1998) Potential threats of poaching of large mammals in Belum and Taman Negara. Journal of Wildlife and Parks (Malaysia), 16, 135-139.

WCS \& TRAFFIC (2004) Hunting and Wildlife Trade In Asia: Proceedings of a Strategic Planning Meeting of the Wildlife Conservation Society (WCS) and TRAFFIC, Bali, Indonesia. WCS and TRAFFIC, Kuala Lumpur, Malaysia.

Wikramanayake, E., Dinerstein, E., Loucks, C., Olson, D., Morrison, J., Lamoreux, J., McKnight, M. \& Hedao, P. (2002) Terrestrial Ecoregions of the Indo-Pacific: A Conservation Assessment. Island Press, Washington, DC, USA.

Wikramanayake, E., McKnight, M., Dinerstein, E., Joshi, A., Gurung, B. \& Smith, D. (2004) Designing a conservation landscape for tigers in human-dominated environments. Conservation Biology, 18, 839-844.

Woodroffe, R. \& Ginsberg, J.R. (1998) Edge effects and the extinction of populations inside protected areas. Science, 280, 2126-2128. 


\section{Appendix}

The appendix for this article is available online at http://journals.cambridge.org

\section{Biographical sketches}

Antony Lynam coordinated an Indochina Tiger Conservation Programme for the Wildlife Conservation Society (WCS) during 1996-2004, during which time he helped train staff, conduct tiger surveys and initiate conservation management programmes in Cambodia, Indonesia, Malaysia, Myanmar and Thailand. Ruth Laidlaw conducted research on effects of habitat disturbance on mammal communities, and during 1999-2001 advised and helped conduct national surveys for tigers in Malaysia on behalf of WCS. Wan Shaharuddin Wan Noordin was a research counterpart on the Malaysia national tiger survey project during 1997-2001. He now directs the Royal Belum State Park. Sivananthan Elagupillay coordinated the national tiger survey project for the Malaysian Government and now directs the Krau Wildlife Reserve. Elizabeth Bennett is Director of WCS's Hunting and Wildlife Trade Program. She worked in Malaysia for more than 2 decades, ultimately leading a team to write Sarawak's comprehensive wildlife policy, then heading a unit within the Government to oversee its implementation. 